\title{
IfIISGUC.ORG
}

"İȘ, GÜC̣" ENDÜSTRi ilLișKiLERI VE INSAN KAYNAKLARI DERGISi

"IS, GUC" INDUSTRIAL RELATIONS AND HUMAN RESOURCES JOURNAL

\section{Örgütsel Adaletin Çalışanların Örgütsel Özdeşleşme Ve İşten Ayrılma Niyetine Etkisi: Örgütsel Özdeşleşmenin Aracılık Rolü}

The Effect Of Organizational Justice And Organizational Identification On Employee's Turnover Intention: The Mediating Effect Of Organizational Identification

Dr. Ömer TURUNÇ

Ocak/January 2011, Cilt/Vol: 13, Say1/Num: 1, Page: 143-166 ISSN: 1303-2860, DOI: 10.4026/1303-2860.2010.0169.x

Makalenin on-line kopyasına erişmek için:

http://www.isguc.org/?p=article\&id=446\&vol=13\&num=1\&year=2011

To reach the on-line copy of article:

http://www.isguc.org/?p=article\&id=446\&vol=13\&num=1\&year=2011

Makale İçin İletişim/Correspondence to: 
(C) 2000- 2011

"İşGüç" Endüstri İlişkileri ve İnsan Kaynakları Dergisi

"İşGüç" Industrial Relations and Human Resources Journal

Ocak/January 2011, Cilt/Vol: 13, Say1/Num: 1

ISSN: 1303-2860, DOI: 10.4026/1303-2860.2010.169.x

Editör/Editor-in-Chief

Aşkın Keser (Kocaeli University)

Editör Yardımcıları/Co-Editors

K.Ahmet Sevimli (Uludağ University)

Gözde Yılmaz (Kocaeli University)

Uygulama/Design

Yusuf Budak (Kocaeli Universtiy)

\author{
Yayın Kurulu / Publishing Committee \\ Dr.Zerrin Firat (Uludăg University) \\ Doç.Dr.Aşkın Keser (Kocaeli University) \\ Prof.Dr.Ahmet Selamoğlu (Kocaeli University) \\ Yrd.Doç.Dr.Ahmet Sevimli (Uludağ University) \\ Yrd.Doç.Dr.Abdulkadir Şenkal (Kocaeli University) \\ Yrd.Doç.Dr.Gözde Yilmaz (Kocaeli University) \\ Dr.Memet Zencirkıran (Uludağ University)
}

Uluslararası Danışma Kurulu / International Advisory Board

Prof.Dr.Ronald Burke (York University-Kanada)

Assoc.Prof.Dr.Glenn Dawes (James Cook University-Avustralya)

Prof.Dr.Jan Dul (Erasmus University-Hollanda)

Prof.Dr.Alev Efendioğlu (University of San Francisco-ABD)

Prof.Dr.Adrian Furnham (University College London-İngiltere)

Prof.Dr.Alan Geare (University of Otago- Yeni Zellanda)

Prof.Dr. Ricky Griffin (TAMU-Texas AEM University-ABD)

Assoc. Prof. Dr. Diana Lipinskiene (Kaunos University-Litvanya)

Prof.Dr.George Manning (Northern Kentucky University-ABD)

Prof. Dr. William (L.) Murray (University of San Francisco-ABD)

Prof.Dr.Mustafa Özbilgin (University of East Anglia-UK)

Assoc. Prof. Owen Stanley (James Cook University-Avustralya)

Prof.Dr.Işık Urla Zeytinoğlu (McMaster University-Kanada)

Danışma Kurulu / National Advisory Board

Prof.Dr.Yusuf Alper (Uludağ University)

Prof.Dr.Veysel Bozkurt (Uludağ University)

Prof.Dr.Toker Dereli (Işık University)

Prof.Dr.Nihat Erdoğmuş (Kocaeli University)

Prof.Dr.Ahmet Makal (Ankara University)

Prof.Dr.Ahmet Selamoğlu (Kocaeli University)

Prof.Dr.Nadir Suğur (Anadolu University)

Prof.Dr.Nursel Telman (Maltepe University)

Prof.Dr.Cavide Uyargil (İstanbul University)

Prof.Dr.Engin Yildırım (Sakarya University)

Doç.Dr.Arzu Wasti (Sabancı University)

Dergide yayınlanan yazllardaki görüşler ve bu konudaki sorumluluk yazarlarına aittir.

Yayınlanan eserlerde yer alan tüm içerik kaynak gösterilmeden kullanılamaz.

All the opinions written in articles are under responsibilities of the outhors.

None of the contents published can't be used without being cited. 


\title{
Örgütsel Adaletin Çalışanların Örgütsel Özdeşleşme Ve İşten Ayrilma Niyetine Etkisi: Örgütsel Özdeşleşmenin Aracılık Rolü
}

\author{
The Effect Of Organizatıonal Justice And Organizational \\ Identification On Employee's Turnover Intention: \\ The Mediating Effect Of Organizational Identification
}

\author{
Dr. Ömer TURUNÇ
}

\begin{abstract}
Özet:
Çalışanların örgütsel adalet algısı pek çok örgütsel davranışın öncülü̈ü̈r. Bu çalışma ile kamu ve özel sektörde faaliyet gösteren iki farklı çalışan grubunda örgütsel adaletin örgütsel özdeşleşme ve işten ayrllma niyeti üzerindeki etkileri araştırılmıştır. Araştırmada kamu ve özel sektör çalışanlarının adalet, özdeşleşme ve işten ayrılma niyeti alğlamaları arasında anlamlı bir fark olduğu belirlenmiştir. Araştırma sonucunda, çalışanların dağıtım adaleti algılamalarının örgütsel özdeșleșme ve ișten ayrılma niyetini anlaml olarak etkilediŏi ve örgütsel özdeșleşmenin dağıtım adaleti - işten ayrılma niyeti arasında aracıllk rolü üstlendiği tespit edilmiştir. Yapılan analizler sonucunda, oluşturulan yapısal eşitlik modeli uyum iyiliği değerlerinin kabul edilebilir düzeyde olduğu belirlenmiş ve ortaya konulan yapısal modelin veriye uygun olduğu belirlenmiştir.
\end{abstract}

Anahtar Kelimeler: Prosedür Adaleti, Dağıtım Adaleti, Etkileşim Adaleti, Örgütsel Özdeşleşme, İşten Ayrılma Niyeti

\begin{abstract}
:
Employee's organizational justice perception is the pioneer of organizational behaviors. Effects of organizational justice on organizational identification and turnover intention is searched at the two different employee's group from public and private sector in this study. It is determined at the study that there is a reasonable difference between public and private sector employees' perception of justice, identification and turnover intention. Results show that employee's distributive justice perception effects reasonably organizational identification. It has also showed that turnover intention and organizational identification has a mediator role between distributive justice and turnover intention. According to the results it is determined that composed structural equation model's goodness of fit values are at the reasonable level and the composed structural equation model is proper for data.
\end{abstract}

Keywords: Procedural Justice, Distributive Justice, Interactional Justice, Organizational Identification, Turnover Intention 


\section{Giriş}

Değişen çalışma yaşamı sürdürülebilir rekabet gücüne ulaşılabilmesi için her türlü işletme fonksiyonunda olduğu gibi insan kaynakları fonksiyonu da önemli değişimler yaşanmaktadır. Organizasyonel başarımın ve verimliliğin en önemli dinamiklerinden olan işgücü unsurunun beklenti ve ihtiyaçları yaşanan değişim çerçevesinde farklılaşmaktadır. Bu kapsamda nitelikli işgücünün işletmede tutulması insan kaynakları yöneticilerinin önemli problemlerinden birisi olarak karşımıza çıkmaktadır.

Yaşanan teknolojik gelişmelerin parelelinde nitelikli işgücüne duyulan ihtiyaç her zamankinden daha fazladır. Nitelikli işgücünün elde tutulması, performansının ve verimliliğinin arttırılması önemli bir gereklilik haline gelmiştir. Nitelikli işgücünü bulmak kadar bu önemli kaynağın işten ayrılmasını önlemek de insan kaynakları yönetiminin öncelikli uğraşlarından birisi haline gelmiştir. Çalışanların işten ayrılma niyetlerinin azaltılması, çalışan verimliliğinin artırılmasında önemli bir yere sahiptir. Nitelikli işgücünün işletmede kalmasının sağlanmasında pek çok sosyal motive edici bulunmaktadır (Brashear vd., 2005).

Özel sektörde olduğu gibi kamu sektöründe de insan kaynakları yönetimi gün geçtikçe artan bir öneme sahip olmaktadır. Ancak çoğunlukla nitelikli işgücüne en az özel sektör kadar ihtiyaç duyan kamu sektörü nitelikli işgücünün beklentilerine cevap verememektedir. Bu çerçevede nitelikli işgücünün işletmede kalmasını sağlayacak faktörlerin ortaya konulması önemli bir çalışma alanıdır. Bu faktörlerin etkilerinin kamu ve özel sektör çalışanlarında farklılaşabileceği düşünülmektedir. Bu bağlamda kamu ve özel sektörde çalışanların işten ayrılma niyetini etkileyen faktörlerin belirlenmesi ve hangi faktörün kamu ve özel sektörde etkili olduğunun belirlenmesi bu çalışmanın sorun alanlarından bir kısmını oluşturmaktadır.

Nitelikli işgücünün işten ayrılma emarelerinden önemli birisi işten ayrılma niyetidir
(Griffeth, Hom ve Gaertner, 2000). Çalışanların işten ayrılma niyetlerini ve davranışlarını belirleyen birçok önemli etmen bulunmaktadır. Genellikle işgörenler potansiyellerini daha verimli kullanabilmek, aldıkları ücret ve ödülleri artırabilmek için işlerinden ayrılırlar (Dreher,1982)

Nitelikli işgücünün işten ayrılma niyetini azalttığ1 düşünülen pek çok değişken bulunmaktadır. Ancak örgütsel davranış değişkenleri ve değişkenlerin diğer bağımlı ve bağımsız değişkenler ile ilişki ve etkileri kültürden kültüre, sektörden sektöre farklılıklar gösterebilmektedir. Bu nedenle doğru değişkenleri ve doğru kombinasyonları oluşturabilmek için farklı sektörlerde çalışmalar yapmak doğru modelin oluşturulmasinda önemli bir yere sahiptir. Mevcut kuram ve uygulamalar paralelinde farklı sektörlerde farklı analiz yöntemleriyle yapılacak araştırmaların organizasyonel verimliğin artırılmasına katkı yapabileceği düşünülmektedir.

$\mathrm{Bu}$ araştırmada çalışanların işten ayrılma niyetine etkisi olduğu düşünülen iki ayrı değişken analiz edilmiştir. Bunlardan ilki örgütsel adalet algisı değişkenidir. $\mathrm{Bu}$ değişken prosedür adaleti, dağıtım adaleti ve etkileşim adaleti boyutlarıyla ele alınmıştır. Araştırmada incelenen ikinci deişken ise örgütsel özdeşleşme değişkenidir. Örgütsel adalet ve örgütsel özdeşleşme pek çok örgütsel davranış değişkeninin öncülü olara karşımıza çıkabilmektedirler. Bu iki değişkenin çalışanların işten ayrılma niyetine etkisi çeşitli çalışmalarda ele alınmıştır. Ancak örgütsel adalet ile işten ayrılma niyetinde örgütsel özdeşleşmenin oynadığ 1 role ilişkin yerli literatürde henüz bir çalışmaya rastlanılmadığı gibi yabancı literatürde ise sınırlı ve dolaylı çalışmalara rastlanmaktadır. Ayrıca sektörlere ve kültürler gibi farklı örneklemlerde değişik sonuçların alınabildiği örgütsel davranış literatüründe bu üç değişkenin toplu olarak analiz edildiği yeterli say1 ve kapsamda çalışmaya rastlanılmamamıştır.. Bununla birlikte konu alınan bu üç değişkeni birlikte ele alan ve oluşturulan yapısal eşitlik modeli ile uyum iyiliği testle- 
rini ortaya koyan çalışmaları da henüz rastlanılmamış olması çalışmanın yapılmasına temel teşkil eden nedenlerden birisidir. Bu çerçevede yapılan bu araştırmanın bundan sonra yapılacak çalışmalar kapsamında önemli bir perspektif olabileceği düşünülmektedir.

Araştırma kapsamında çoğunlukla nitelikli işgücü istihdamının bulunduğu bankacılık ve savunma sektöründe çalışanların işten ayrılma niyetinde örgütsel adalet alg1larının etkileri araştırılmıştır. Bu etkileri araştırırken örgütsel özdeşleşme değişkeninin iki değişken arasında ne gibi bir etkisi olduğu da incelenmiştir. $\mathrm{Bu}$ çerçevede çalışanların örgütsel adalet algısı ve örgütsel özdeşleşme düzeylerinin işten ayrılma niyetine olan etkileri oluşturulan yapısal eşitlik modeli ile analiz edilmiştir.

Günümüzde nitelikli işgücünü elde bulundurmak önemli bir kritik başarı faktörüdür. Bankacılık sektörü gini bilgi çağının önde gelen özel hizmet sektörlerinde ve savunma sektörü gibi nitelikli teknolojik yenilikler gerektiren bir kamu sektöründe nitelikli işgücü önemli bir kritik başarı faktörüdür. Bankacılk sektöründe faaliyet gösteren özel bir bankanın belirli bir kesiminde ve kamusal savunma sektöründe yapılan bu araştırma kapsamında banka çalışanlarının ve savunma sektörü çalışanlarının işten ayrilma niyetine örgütsel adalet algılarının ve örgütsel özdeşleşme düzeylerinin etkileri araştırılmıştır. Araştırma ve bulgulara değinilmeden önce araştırma değişkenleri ve bu değişkenlerin diğer değişkenlerle ilişkileri ortaya konulmuştur. Her bir değişken ayrı ayrı ele alınırken araştırmanın temelini oluşturan kuram ortaya konulmuş ve bu kuram kapsamında yapılan değerlendirmeler 1ş1ğında araştırılacak olan hipotezler sunulmuştur.

\section{Kuramsal Çerçeve}

\section{1.Örgütsel Adalet}

İşletmelerde adillik rolü örgütsel adalet kavramiyla örgütlerde yer bulmaya ve sosyal adaletin işletmelerde önemi geçtikçe daha çok artmaya başlamıştır(Greenberg,1990). Bireyin örgütündeki uygulamalarla ilgili olarak adalet algilaması olarak nitelenebilen örgütsel adalet alg1sı değişen çalışma yaşamıyla birlikte daha etkin bir hal almaktadır (Greenberg,1996:24). Nitekim bilgi ve iletişim teknolojilerindeki gelişmeler sayesinde çalışanlar gerek işletme içi gerekse işletme dişı faaliyet ve uygulamalardan çok kısa sürelerde çok geniş kapsamlı bir şekilde haberdar olabilmektedirler. Özellikle nitelikli işgücüne sahip işletmeler çalışanların örgütsel adalet algılarına kayıtsız kalamamaktadırlar. Çünkü nitelikli işgücünün önemli bir beklentisi haline gelen örgütsel adalet çalışanın iş ile ilgili kararlarını etkileyebilmektedir.

Örgütsel adalet, kazanılanların dağıtılması ve dağıtım kararlarının alınmasında kullanılan prosedürler ve bireyler arası etkileşimin gerektirdikleri ile ilgili geliştirilen kurallar ve sosyal normlarla açıklanmaktadir (Folger vd., 1998; Greenberg, 1990).

Örgütsel adalet kavramı Adams'in $(1963,1965)$ eşitlik teorisi'ne (Equity Theorie) kadar uzanmaktadır (Greenberg, 1990). Eşitlik teorisi örgüt bilimcilerin dikkatini adalet çalışmalarıyla ilgilenmeye yöneltmiştir (Mowday,1987). Örgütsel adalet, kazanılanların dağıtılması ve dağıtım kararlarının alınmasında kullanılan prosedürler ve bireyler arası etkileşimin gerektirdikleri ile ilgili geliştirilen kurallar ve sosyal normlarla açıklanmaktadır (Folger vd., 1998; Greenberg, 1990).

Örgütsel adalet kavramı başlangıcı itibariyle eşitlik teorisi ile ilişkilendirilmesine rağmen devam eden süreçler ve çalışmalarla farklı çalışma alanlarıyla irdelenmiştir. Örgütsel adalet algısının daha iyi anlaşılabilmesi maksadıyla çeşitli boyutlandırmalar yapılmıştır. Örgütsel adalet olgusu alt boyutlarına ilişkin tartışmalar olsa da "dağıtım adaleti", "prosedür adaleti" ve "etkileşim adaleti" olarak adlandırılan üç boyuttan meydana gelen bir kavram olarak karşımıza çıkmaktadır(Greenberg, 1987, 1988, 1993, 1996; Alexander ve Ruderman, 1987; Lind, 1995, Lind ve Tyler, 1988; Fryxell ve Gor- 
don, 1989; Folger ve Konovsky, 1989; Sheppard vd., 1992; Cropanzano ve Randall, 1993; Gordon ve Fryxell, 1993; Hartley, 1995; Alexander vd., 1995; Taylor vd.,1995; Cropanzano ve Kackmar; 1995; Beugre, 1998; Folger ve Cropanzano, 1998; Folger ve Konovsky,1989; Chang, 2002; Tornblom,1990).

Çalışanlar genellikle organizasyonda kendilerine adil davranılıp davranılmad1ğına; kendilerinin organizasyona verdiği çaba, zaman ve buna benzer katkılar ile bunun karşılığında organizasyondan elde ettiği ücret, terfi gibi kazançlarını karşılaştırarak yapmaktadır. Bu karşılaştırmalar sonucunda, çalışanlar örgütsel adalet bağlaminda organizasyonundaki kaynakların dağıtımına ilişkin adil davranıldı̆̆ına yani "dağıtım adaleti" algısına, bunlarla ilgili alınan kararlardaki yöntem ve süreçlerle ilgili "prosedür adaleti" algisına ve son olarak bu prosedürün uygulanması esnasındaki bireyler arası etkileşimiyle ilgili "etkileşim adaleti" algısına sahip olmaktadirlar.

Örgütsel adaletin üçüncü boyutu olarak pek çok çalışmada ele alınan etkileşim adaleti genellikle prosedür adaleti kapsaminda ele alınmaktadır (Masterson vd., 2000). Ancak çalışanların adalet algısının bireyler arası ilişkiler çerçevesinde pratik hale dönüştügünden hareketle etkileşim adaletinin örgütsel adalet algısında önemli bir boyut olduğu pek çok araştırmada kabul edilmektedir (Greenberg, 1996; Gordon ve Fryxell, 1993; Taylor vd.,1995).

Sosyal bilimciler adaletin örgüt verimliliğindeki önemini kabul etmektedirler (Moore, 1978; Okun, 1975). Organizasyondaki adalet çalışanın işyerindeki davranışının ya da alışkanlıklarının önemli bir belirleyicisidir (McFarlin ve Sweeney, 1992). $\mathrm{Bu}$ nedenle organizasyonların başarımında örgütsel adalet olgusunun önemli etkilerinin olabileceği değerlendirilmektedir.

\section{2.Örgütsel Özdeşleşme}

19. yy. sonlarında kişilerin çalıştıkları organizasyonla kurdukları bireysel psikolojik ilişkiler incelenmeye başlanmıştır (Kreiner ve Ashforth, 2004). Örgütsel adalet algisının çalışanların çalıştıkları organizasyonla aralarında olan abağ güçlendirdiği düşünülmektedir. Çalışanların örgütleri ile aralarındaki bağ 1 belirlemeye yönelik çalıșmalarda öne çıkan kavramlardan bir tanesi de örgütsel özdeşleşmedir. Bu kapsamda incelenen önemli bir değişken olan örgütsel özdeşleşme, örgüt ile birey arasındaki ilişkiyi açıklamaya yardım eder (Tompkins ve Cheney, 1985). Ashforth ve Mael (1989). Örgütsel özdeşleşme; başarı ve başarısızlık durumlarını da içeren, ait olma ya da birlik olma algılayışı olarak tanımlamaktadır. Kişinin kendisi ile örgütü tanımlaması arasındaki bilişsel bağ olarak tanımlanan (Dutton, Dukerich ve Harquail, 1994) örgütsel özdeşleşmeyi Scott ve Lane (2000), psikolojik olarak örgütü kendinin bir parçası olarak hissetmek olarak açıklamışlardır. Çalışanların başarıda veya başarısızlıkta gruba (organizasyona) ait olma ya da grupla birlik olma alg1s1 (Ashforth ve Mael, 1989) veya psikolojik olarak örgütü kendinin bir parçası olarak hissetmesi şeklinde de tanımlanan (Scott ve Lane, 2000) örgütsel özdeşleşme, gün geçtikçe daha fazla çalışılan bir konu olarak literatürde yer almaktadır. Örgütüyle özdeşleşen çalışanlar, örgüt dışındaki insanlarla etkileşimde kendilerini örgütün temsilcisi olarak görme eğiliminde olurlar. Bu çalışanlar, stratejik ve iş kararlarına yönelik fırsatlarda kurumun menfaatini önde tutarlar (Miller ve diğerleri, 2000). Özdeşleşme bireyin sosyal kimliklerinin bir parçası olarak örgütsel kimliğin bir sonucudur (Ashforth ve Mael, 1989). Pratt (1998), örgütle özdeşleşmenin bireyin bütünsel ihtiyaçlarını tatmin ettiğini belirtmiştir.

Örgütler çalışanların örgütle özdeşleşmelerini sağlamak için değerlere dayanan teşvikleri aktif olarak sunarlar (Cheney, 1983). Bunun yanında çalışanların örgütsel özdeşleşme düzeylerinin yükseltilmesinin pek çok değişkenin öncülü olabileceği de değerlendirilmektedir. Örgütsel özdeşleşme ile pek çok değişken arasındaki ilişki ve etkiyi belirlemek maksadıyla çok sayıda çalışma yapılmıştır. Çalışan ile organizasyon arasındaki ilişkinin çalışan penceresinden 
görüntüsü, örgütsel bağl1lıktan farklı bir ilişki olarak örgütsel davranış yazınında ayrı bir yer oluşturmaktadır. Benlik bağlamının ve bir olma (oneness) algısının göstergesi özdeşleşme, kişi - örgüt uyumu ve örgütsel bağlılık gibi ilişkili yapılardan ayrılmaktadır (Kreiner ve Ashforth, 2004).

\section{İşten Ayrulma Niyeti}

Örgütsel adalet alg1sı günümüzde pek çok örgütsel davranış değişkeninin öncülü olarak karşımıza çıkabilmektedir. Çalışanların çalıştıkları organizasyonun çalışanlara her türlü konuda adil olması konusundaki algıları başta işte kalma kararları olmak üzere pek çok kararlarına temel teşkil edebilmektedir(Sweeney ve McFarlin, 1997).

İşe devam olgusu yönetim araştırmalar1nin temel konularından birisidir. Shaws ve arkadaşları(1998) bu konu ile ilgili 1500 kadar araştırma olduğunu bildirmiştir. İsten ayrılma niyeti çalışanların istihdam koşullarından tatminsiz olmaları durumunda gösterdikleri negatif bir davranıştır(Rusbelt vd.,1988). Çalışanların isten ayrılması sorunu, çalışan davranışları ve bu davranışların ilişkili olduğu faktörler araştırılıyor olmasına rağmen halen organizasyonlar için önemli bir problem sahası olma niteliğini taşımaktadır (Porter vd., 1973, s.603). Yüksek performanslı çalışanların işten ayrılmaları bir örgüt için hiç istenmeyen bir durum iken, düşük performanslı çalışanların işten ayrılması bir örgüt için fonksiyonel ve pozitif bir durumdur (Jackofsky, 1984; DeConninck ve Bachmann, 2005). Wood (1997), işten ayrılma niyetinin hizmet sektöründe olumlu ve olumsuz etkilerinin olduğunu bildirmiştir.

Çalışanların işte devam kararı aynı bağlamda işten ayrılma niyeti ile doğrudan ilişkili bir karardır. O halde çalışanların işten ayrılma niyetinin oluşmasında temel etkenlerden bir tanesinin de çalışanların örgütsel adalet algısı olabileceği düşüncesi araştırmacıları konu ile direkt ya da dolaylı araştırmalara yöneltmiş olup konu ile ilgili yapılmış çeşitli çalışmalar bulunmaktadır (Nadiri ve Tanova, 2009; Fields vd., 2000).

\section{Hipotezlerin Oluşturulması}

Bugüne kadar araştırmacılar tarafından hem örgütsel adalet kavramı hem de alt boyutlarının farklı değişkenlerle etki ve ilişkilerinin ortaya çıkarılmasına yönelik çok sayıda çalışma yapıldığ görülmektedir. Örneğin, Çalışanların örgütsel adalet algılarının, örgütsel vatandaşlık davranışı, yöneticiye duyulan güven, iş tatmini, örgütsel bağlılık, kararlara katılma isteği ve çal1şan sağlı̆̆ gibi farklı değişkenlere etkilerini incelenmiş ve sonuçta yüksek adalet algıs1nın bu değişkenlerle pozitif ve anlamlı olarak ilişkili oldukları rapor edilmiştir (Folger,1989; Tang vd.,1996). Ayrıca, örgütsel adalet kavramının alt bileşenlerinin farklı değişkenlerle ilişki ve etkileri de incelenmiştir. Bu bağlamda, çalışanların kararlara katılımı konusundaki motivasyon beklentilerinin prosedür adaleti algılama düzeyleri ile ilişkili olduğu (Leventhal, 1980; Thibaut ve Walker, 1975, 1978), çalışanların iş tatmini ile prosedür adaleti arasında pozitif ve anlamlı bir ilişki olduğu (DeCremer ve Stouten, 2005; DeCremer, 2006), içsel motivasyon ile etkileşim adaleti arasında anlamlı ilişkiler bulunmuştur (Chebat ve Slusarczyk, 2005; Barclay vd., 2005; ZapataPhelan vd, 2009; Miao ve Evens, 2007; Steensma ve Visser, 2007).

Prosedür adaleti çalışanların kararlara katılması bağlamında önemli bir yere sahiptir (Brett ve Goldberg 1983; Lind ve Tyler, 1988). Yapılan birçok araştırmada prosedür adaleti iş performansı arasında anlamlı ve pozitif bir ilişki belirlenmiştir (Williams, 1999; Nurse, 2005; Ang vd., 2003; Lindquist, 1995; Byrne, 2005).

Örgütsel adalet ile örgütsel özdeşleşme arasındaki ilişkiyi ve örgütsel adalet boyutlarının örgütsel özdeşleşme üzerindeki etkileri belirlemeye yönelik çeşitli çalışmalar bulunmaktadir. Olkkonen ve Lipponen (2006), 270 çalışan üzerinde yaptıkları bir araştırma sonucunda dağıtım ve prosedür adaleti ile örgütsel özdeşleme arasında pozitif - anlamlı ilişki olduğunu ve dağıtım ve prosedür adaletinin örgütsel özdeşleşmeyi pazitif ve anlamlı olarak etkilediklerini be- 
lirlemiştir. Ancak bu araştırmada etkileşim adaleti ile örgütsel özdeileşme arasında anlamlı bir ilişki olmadığ 1 ve etkileşim adaletinin örgütsel özdeşleşme üzeride anlamlı bir etkisi olmadığ 1 da belirlenmiştir.

Cheung ve Law (2008) üç yapı hizmet organizasyonunda 159 proje kontrol departmanı üzerinde yaptıkları çalışmada örgütsel adaletin üç boyutu olan dağıtım, prosedür ve etkileşim adaletinin örgütsel özdeşleşme ile pozitif ve anlamlı ilişkisi olduğunu belirlemişlerdir.

Bu kapsamda literatürde konu ile ilgili bu çalışmalardan yola çıkılarak çalışanların prosedür, dağıtım ve etkileşim adaleti algılamalarının örgütsel özdeşleşme düzeyleri üzerindeki etkilerini test etmek üzere üç hipotez oluşturulmştur. Bunlar:

Hipotez 1a: Çalışanlarmm prosedür adaleti algısı örgütsel özdeşme düzeylerini pozitif ve anlamlı olarak etkiler.

Hipotez 1b: Çalışanlarının dağıtım adaleti algısı örgütsel özdeşleşme düzeylerini pozitif ve anlamlı olarak etkiler.

Hipotez 1c: Çalışanlarmın etkileşim adaleti algısı örgütsel özdeşleşme düzeylerini pozitif ve anlamlı olarak etkiler.

Çalışanların örgütsel adalet algısı ile iş tatmini, işten ayrılma niyeti, iște kalma niyeti gibi bireysel çıktıları arasındaki ilişkinin konu olduğu çalışmalara da literatürde sıkça rastlanilabilmektedir. (Folger ve Konovsky, 1989; McFarlin ve Sweeney, 1992; Cropanzano ve Folger, 1991; Cropanzano ve Randall, 1993; Sweeney ve McFarlin, 1997). Dağıtım adaleti gibi bireysel beklentilerle önemli ilintisi olan dengeler çalışanların işte kalma kararında önemli bir etken olarak algilanabilmektedir. (Greenberg, 1987)

Prosedür adaleti ile İAN arasındaki negatif yönlü ilişkilere yönelik pek çok araştırma bulunmaktadir (DeCorninck ve Stilwell, 2004; Byrne, 2005; Colquitt vd. 2001; Brashear vd., 2005). Dağıtım adaleti ile İAN arasında da negatif yönlü ilişki olduğunu belirleyen araştırmalar mevcuttur (Colquitt vd. 2001; Brashear, 2005; McFarlin ve Swee- ney, 1992).

Nadiri ve Tanova (2009), otel işletmelerinde yapmış oldukları bir çalışma sonucunda örgütsel adaletin boyutları olan dağıtım, prosedür ve etkileşim adaletinin çalışanların işten ayrılma niyeti ile negatif ve anlamlı ilişkisi olduğunu belirlemişlerdir. Aynı çalışmada otel çalıșanlarının dağıtım, prosedür ve etkileşim adaletini algılarının işten ayrılma niyetini negatif ve anlamlı olarak etkilediği tespit edilmiştir. Bu çalışmalar örgütsel adalet algısı yükseltilen çalışanların işten ayrılma niyetlerinin azalacağını ortaya koymaktadır. Bu kapsamda literatürde konu ile ilgili bu çalışmalardan yola çıkılarak çalışanların prosedür, dağıtım ve etkileşim adaleti algilamalarının işten ayrılma niyeti üzerindeki etkilerini test etmek üzere şu hipotezler oluşturulmştur.

Hipotez 2a: Çalışanlarmın prosedür adaleti algısı işten ayrilma niyetini negatif ve anlaml olarak etkiler.

Hipotez 2b: Çalışanlarının dağıtım adaleti algisı işten ayrulma niyetini negatif ve anlamlı olarak etkiler.

Hipotez 2c: Çalışanlarmın etkileşim adaleti algısı işten ayrulma niyetini negatif ve anlaml olarak etkiler.

Örgütsel adaletin işten ayrılma niyetine etkisini belirlemeye yönelik çalışmalara bakıldığında direkt etkileri ele alan çalışmalar olduğu gibi dolaylı etkileri de ele alan çalışmalar olduğu görülmektedir. Bu çalışmalardan hareketle bir bağımlı değişken olan işten ayrılma niyetinin azaltılmasında örgütsel adalet algısının yanında elbette başka değişkenlerinde olabileceği konusu örgütsel özdeşleşme değişkeninin incelenmesinin temel nedenini oluşturmuştur. Nitekim örgütsel özdeşleşme yapılan çalışmalarda örgütsel adaletin ardılı olarak görülebildiği gibi işten ayrılma niyetinin öncülü olarak da görülebilmektedir. Bu noktadan hareketle araştırmada hem örgütsel adaletin örgütsel özdeşleşme ve işten ayrılma niyeti üzerindeki etkileri incelenirken hemde örgütsel özdeşleşmenin işten ayrılma niyeti üzerindeki etkilerinin ortaya konulması hedeflenmiştir. 
Bu sayede örgütsel özdeşleşmenin örgütsel adalet- ișten ayrılma niyeti ilișkisindeki rolü ( aracılık rolü) konusunda bilgi edinilmeye çalışılmıştır.

Literatürde örgütsel özdeşleşme ile işten ayrılma niyeti arasındaki direkt ve dolaylı ilişki ve etkileri ele alan çeşitli çalışmalar bulunmaktadır. Dick ve arkadaşları(2004) iki banka, bir hastane ve bir çağrı merkezi olmak üzere dört ayrı örneklem üzerinde yapmış oldukları bir araştırma sonucunda her dört örneklemde de örgütsel özdeşleşmenin çalışanların işten ayrılma niyetini negatif ve anlamlı olarak etkilediğini belirlemiştir. Mignonac ve arkadaşları (2006) yapmış oldukları bir araştırma kapsamında yönetici, mühendis ve kontrolör olmak üzere üç ayrı örneklem üzerinde yapmış olduğu bir çalışmada kontrolör örneklemi haricinde negatif ve anlamlı bir ilişki tespit edilememiştir. Van Knippenberg ve Van Schie (2000) de biri Hollanda yönetim biriminde çalışanlar diğeri bir üniversite fakültesinde çalışanlar olmak üzere olmak üzere iki ayrı örneklem üzerinde yapmış oldukları bir analiz sonucunda da örgütsel özdeşleşme ile işten ayrılma niyeti arasında anlamlı bir ilişki tespit edememişlerdir. Aynı şekilde Van Knippenberg ve Sleebos (2006) üniversite çalışanları üzerinde yapmış oldukları bir araştırma sonucunda örgütsel özdeşleşme ile işten ayrılma niyeti arasında anlamlı bir ilişki tespit edememişlerdir.

Bu kapsamda literatürde konu ile ilgili bu çalışmalardan yola çıkılarak çalışanların örgütsel özdeşleşme algılamalarnın işten ayrılma niyeti üzerindeki etkilerini test etmek üzere Hipotez 3 oluşturulmuştur.

Hipotez 3: Çalışanlarmın örgütsel özdeşleşme algisı işten ayrulma niyetini negatif ve anlamli olarak etkiler.

Oluşturulan bu hipotezlerin yanında örneklemin yapısında yola çıkılarak iki bağımsız değişkene göre ele alınan bağımlı değişkenler arasında anlamlı bir fark olup olmadığı sorusunun da cevabı aranmıştır. Bu kapsamda öncelikle araştırmlarda sıkça araştırılan cinsiyet demografikeni incelen- miştir. Örneklemde bulunan kadın ve erkeklerin örgütsel adalet ve boyutları, örgütsel özdeşleşme ile işten ayrılma niyeti algilamaları arasında anlamlı bir fark olup olmadığı araştırılmıştır. Ardından örneklemi oluşturan kamu ve özel sektör çalışnlarının örgütsel adalet ve boyutları, örgütsel özdeşleşme ile işten ayrılma niyeti algılamaları arasında anlamlı bir fark olup olmadığı araştırılmıştır.

\section{Araştırmanın Yöntemi}

Çalışanların örgütsel adalet algılarının ördütsel özdeşleşme düzeyleri ve işten ayrılma niyetine etkisinin blirlemeye yönelik araştırmada öncelikle örneklem ve ölçeklere ilişkin bilgilere yer verilmiştir. Ardından örneklemlerden elde edilen veriler ışığında oluşturulan modele ilişkin analizler yapılmıştır. Öncelikle her bir değişkenin doğrulayıcı faktör analizi yapılmış ardından değişkenler arası korelasyonlar tespit edilmiştir. Ardından mevcut modele ilişkin kurulan yapısal eşitlik modeli ile modelin toplu halde uyum iyiliği testleri yapılmıştır. Uyum iyiliği testleri yapılırken değişkenler arası regresyon analiz sonuçları ve hipotez test sonuçları da sunulmuştur. Tüm bu analizler sonucunda elde edilen bulgular mevcut literatür ile karşılaştırılarak yönetici ve araştırmacılara önerilerde bulunulmuştur. Kuramdan yola çıkılarak oluşturulan hipotezler kapsamında yapılandırılan araştırma modeli Şekil 1' de sunulmuştur.

\subsection{Araştırmanın Örneklemi}

Araştırmanın ana kütlesini Ankara'da faaliyet gösteren savunma sektörü çalışanları (kamu) ile özel bir bankanın Ankara ve çerce illerindeki şubelerinde çalışan personel oluşturmaktadır. Bu iki örneklemde toplam 880 kişi çalışmaktadır. Ana kütleden $\% 95$ güvenilirlik sınırları içerisinde $\% 5^{\prime}$ lik bir hata payı dikkate alınarak örneklem büyüklüğü 268 kişi olarak hesap edilmiştir (Sekaran, 1992:253). Bu kapsamda kümelere göre örnekleme yöntemiyle tesadüfi olarak seçilen toplam 400 kişiye anket uygulaması yapılması planlanmıştır. Gönderilen anketlerden 327'si geri dönmüş, 320 tanesi analiz 


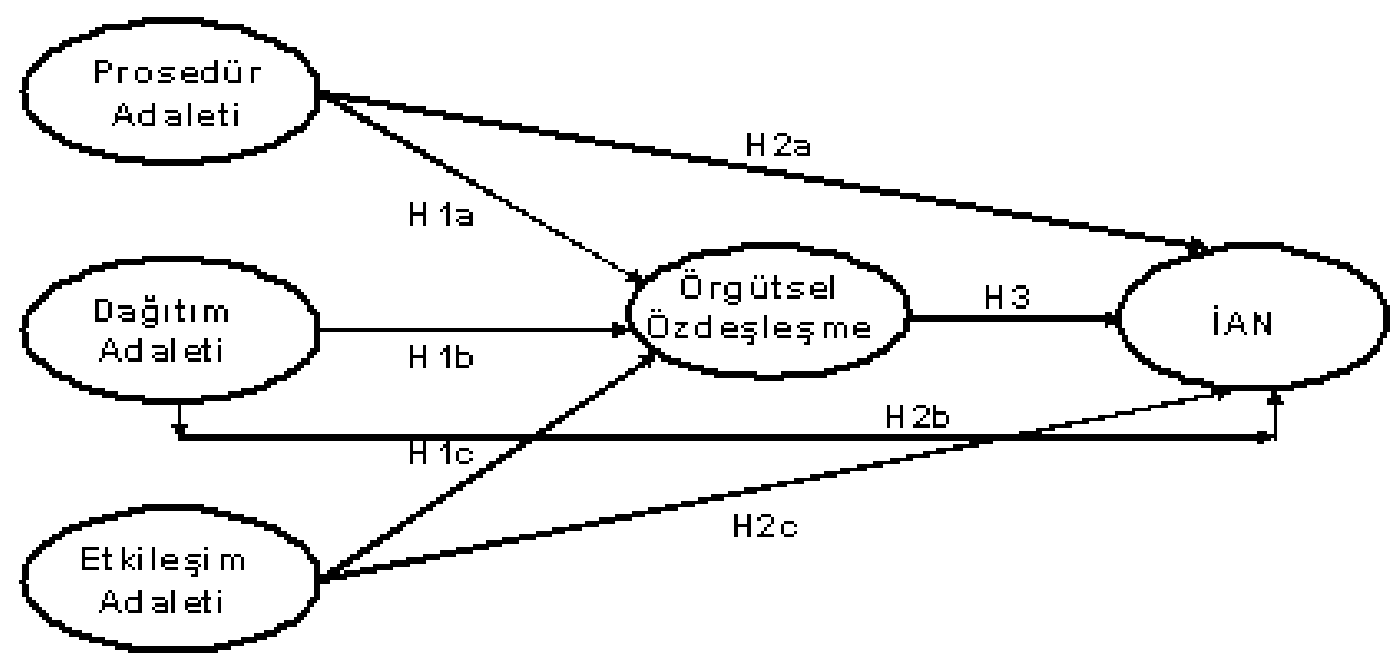

Şekil 1

Araştırmanın Örneklemi

yapmak için uygun bulunmuştur. Araştırmaya katılanların \%53,1'i kadın ( $\mathrm{n}=170)$, $\% 46,9^{\prime} \mathrm{u}(\mathrm{n}=150)$ erkektir. Çalışanların \%3,1'i $(\mathrm{n}=10)$ lise, \%64,1'i $(\mathrm{n}=205)$ üniversite, $\%$ $32,8^{\prime} i$ de $(n=102)$ de lisansüstü eğitim derecesine sahiptir. \%9,1 'i (n=29) 18-24, \%34,4'ü $(\mathrm{n}=110)$ 24-31, \%17,2'si $(\mathrm{n}=55)$ 32-38 ve $\% 39,4^{\prime} \ddot{u}(\mathrm{n}=126)$ de 39 ve yukarı yaşlar arasindadır. \%3,4'ü ( $n=11) 1$ yıldan az, \%32,2'si $(\mathrm{n}=103)$ 1-5 yıl aras1, \%11,9'u (n=38) 6-10 yıl aras1, \%15'i (n=48) 11-15 yıl aras1 ve \%37,5'i $(\mathrm{n}=120)$ de 16 ve yukarı yıl iş deneyimine sahiptir. Araştırmaya katılanların \%65,3'ü $(n=209)$ evli, \%33,1'i $(n=106)$ bekar ve \%1,6 's1 da $(n=5)$ diğer medeni hale sahiptir. Ayrıca çalışanların \%35,9'u ( $\mathrm{n}=115)$ kamuda \%64,1'i ise ( $n=205)$ özel sektörde çalışmaktadir.

\subsection{Araştırmanın Ölçekleri}

Çalışanların işten ayrılma niyetin azaltılmasında örgütsel adalet adalet ve örgütsel özdeşleşmenin rolünü belirlemek amacıyla araştırmada kullanılan ölçeklere ilişkin bilgiler aşağıda verilmektedir. Araştırmada oluşturulan modelleri ve hipotezleri test etmek amacıyla gizli(latent) değişkenlerle yol analizi yapılmıştır. Gizli değişkenlerle yol analizi yapmak için modeldeki değişkenlerin ölçülmesinde kullanılan bütün ölçüm araçlarının geçerli ve güvenilir olması gerekmektedir (Şimşek, 2007: 19). Bu amaçla, araştırmada kullanılan bütün ölçeklere ilişkin yapılan geçerlilik ve güvenirlilik çalışmalarına ilişkin sonuçlar, her ölçekle ilgili bölümün sonunda verilmiştir.

Prosedür adaleti ölçeği: Çalışanların prosedür adaleti algılarını ölçmek üzere Moorman (1991) tarafından geliştirilen ve Niehoff ve Moorman (1993) tarafından geçerleme çalışması yapılan prosedür adaleti ölçeği kullanılmıştır. Toplam 6 ifadeden oluşan bu ölçekte cevaplar 5'li likert ölçeği ile alınmıştır (1=Kesinlikle katılmıyorum, 5=Kesinlikle katıliyorum). Niehoff ve Moorman (1993) tarafından yapılan güvenilirlik analizleri sonucunda, prosedür adaletinin Cronbach alfa güvenirlik katsayısının .85 olduğu tespit edilmiştir. Ölçeğin Türkçeye çok sayıda çevirisi ve uyarlaması mevcuttur. Bu çalışmada Karaeminoğulları (2006) tarafından Türkçe'ye uyarlaması yapılan ölçek kullanılmıştır. Karaeminoğulları (2006) tarafından yapılan güvenilirlik analizleri Cronbach alfa güvenirlik katsayısı .92 olarak tespit edilmiştir. 
Bu çalışmada ölçeğin yapı geçerliliğini test etmek maksadıyla doğrulayıcı faktör analizi yapılmıștır. Faktör analizi sonucunda verilerin ölçeğin tek faktörlü yapısına uyum sağladığ 1 ve faktör yüklerinin .55 ile .76 arasinda olduğu tespit edilmiştir. Yapılan güvenirlik analizi sonucunda ölçeğin toplam Cronbach alfa güvenirlik katsayısı .76 olarak bulunmuştur.

Etkileşim adaleti ölçeği: Çalışanların etkileşim adaleti algılarını ölçmek üzere Moorman (1991) tarafından geliştirilen ve Niehoff ve Moorman (1993) tarafından geçerleme çalışması yapılan etkileşim adaleti ölçeği kullanılmıştır. Toplam 9 ifadeden oluşan bu ölçekte cevaplar 5'li likert ölçeği ile alınmıştır ( $1=$ Kesinlikle katılmiyorum, $5=$ Kesinlikle katıliyorum). Niehoff ve Moorman (1993) tarafından yapılan güvenilirlik analizleri sonucunda etkileşim adaleti için Cronbach alfa güvenirlik katsayısı .92 olarak tespit edilmiştir. Ölçeğin Türkçeye çok sayıda çevirisi ve uyarlaması mevcuttur. Bu çalışmada Karaeminoğulları (2006) tarafından Türkçe'ye çevirilen ve öğretim üyelerinde kullanılan ölçek kullanılmıştır. Karaeminoğulları (2006) tarafından yapılan güvenilirlik analizleri sonucunda Cronbach alfa güvenirlik katsayısı .97 olarak tespit edilmiştir.

Ölçeğin yapı geçerliliğini test etmek maksadıyla doğrulayıcı faktör analizi yapılmıştır. Faktör analizi sonucunda verilerin ölçeğin tek faktörlü yapısına uyum sağladığı ve faktör yüklerinin .77-.89 arasında olduğu tespit edilmiştir. Yapılan güvenirlik analizi sonucunda ölçeğin toplam Cronbach alfa güvenirlik katsayısı .95 olarak bulunmuştur.

Dağıtım adaleti ölçeği: Çalışanların etkileşim adaleti algılarını ölçmek üzere Moorman (1991) tarafından geliştirilen ve Niehoff ve Moorman (1993) tarafından geçerleme çalışması yapılan etkileşim adaleti ölçeği kullanılmıştır. Toplam 5 ifadeden oluşan bu ölçekte cevaplar 5'li likert ölçeği ile alınmıştır (1=Kesinlikle katılmıyorum, 5=Kesinlikle kat1lyyorum). Niehoff ve Moorman (1993) tarafından yapılan güvenilirlik analizleri sonucunda dağıtım adaleti için Cronbach alfa güvenirlik katsayısı .91 olarak tespit edilmiştir. Ölçeğin Türkçeye çok sayıda çevirisi ve uyarlaması mevcuttur. Bu çalışmada Karaeminoğulları (2006) tarafından Türkçe'ye çevirilen ve öğretim üyelerinde kullanılan ölçek kullanılmıştır. Karaeminoğulları (2006) tarafından yapılan güvenilirlik analizi sonucunda ölçeğin Cronbach alfa güvenirlik katsayısı .86 olarak tespit edilmiştir.

Ölçeğin yapı geçerliliğini test etmek maksadıyla doğrulayıcı faktör analizi yapılmıştır. Faktör analizi sonucunda verilerin ölçeğin tek faktörlü yapısına uyum sağladığı ve faktör yüklerinin .55-.80 arasında olduğu tespit edilmiştir. Yapılan güvenirlik analizi sonucunda ölçeğin toplam Cronbach alfa güvenirlik katsayıs1 .81 olarak bulunmuştur.

Örgütsel Özdeşleme Ölçĕ̆i: Örgütsel özdeşleşmenin gücünün belirlenmesinde, Mael ve Ashforth (1992) tarafından geliştirilen ve pek çok diğer araştırmada kullanılan (Örneğin; Tüzün, 2006; Bhattacharya ve diğerleri, 1995; Mael ve Tetrick, 1992; Mael ve Ashforth, 1992; Van Knipperberg ve Van Schie, 2000; Smidths ve diğerleri, 2001) örgütsel özdeşleşme ölçeği kullanılmıştır. Toplam 6 ifadeden oluşan bu ölçekte cevaplar 5'li likert ölçeği ile alınmıştır (1=Kesinlikle katılmiyorum, 5=Kesinlikle katılıyorum). Mael ve Ashforth (1992) araştırmasında ölçeğin güvenirlik katsayısını .87 olarak bildirmiştir. Tüzün (2006) araştırmasında kullandığ1 ölçeğin güvenilirlik katsayısını .78 olarak bildirmiştir.

Yapılan doğrulayıcı faktör analizi sonucunda ölçeğin tek faktörlü yapıya sahip olduğu, faktör yüklerinin .45-.77 arasında değiştiği belirlenmiştir. Ölçeğin Cronbach alfa güvenirlik katsayısı .76 olarak tespit edilmiştir.

İşten Ayrulma Niyeti Ölçeği: Çalışmada yer alan işten ayrılma niyeti ölçeği Wayne, Shore ve Linden (1997) tarafından geliştirilmiştir. Bu ölçekte işten ayrılma eğilimi üç ifade ile ölçülmekte olup ölçek tek boyutludur. Küçükusta (2007) tarafından konaklama işletmelerinde uygulanmış ve bu çalışmada ölçek güvenilirliği 0,69 olarak bildirilmiştir. 
Cevaplar 5'li likert (1=Kesinlikle katılmıyorum, 5=Kesinlikle katılıyorum) ölçeği ile alınmıştır.

Yapılan doğrulayıcı faktör analizi sonucunda ölçeğin tek faktörlü yapıya sahip olduğu, faktör yüklerinin .84-.92 arasinda değiştiği belirlenmiştir. Ölçeğin Cronbach alfa güvenirlik katsayısı .89 olarak tespit edilmiştir.

\subsection{Bulgular}

Araştırma sonucunda elde edilen verilere SPSS 16 ve Amos 7.0 programinda analizler yapılmıştır. Bu kapsamda, ilk aşamada katılımcıların prosedür adaleti algısı, dağıtım adaleti alg1sı, etkileşim adaleti algısı, örgütsel özdeşleşme algısı ve işten ayrılma niyetine ilişkin elde edilen verilerin ortalamaları, standart sapmaları ve aralarındaki korelasyonlara bakılmıştır. Analizin ikinci aşamasında ise yapısal eşitlik modeli ile kurulan modele ilişkin yol analizi yapılmıştır. Yapılan yol analizi ile çalışmanın hipotezleri test edilirken, mevcut ilişkileri açıklayan en uygun modelin belirlenmesi de amaçlanmiştır.

Analiz sonucunda elde edilen ortalamalar, standart sapmalar ve korelasyon değerleri tablo 1'de verilmektedir. Görüldüğgü gibi araştırma kapsamında incelenen tüm bağımlı ve bağımsız değişkenler arasında anlamlı ilişki bulunmaktadır.

Tablo 1 'de de görüldüğü gibi araştır- maya konu edilen tüm bağımlı ve bağımsız değișkenler arasında anlamlı ilişkiler bulunmaktadır. Bu anlamlı bulguların devamında yapısal eşitlik modeli çerçevesinde yol analizi yapılarak değişkenler arası etkiler ve modelin uyum iyiliği değerlerine bakılmıştır.

Ancak yapilacak olan yol analizinden önce ele alınan örneklemden yola çıkılarak t testleri yapılmıştır. Yapılan $\mathrm{t}$ testi kapsaminda öncelikle cinsiyet değişkeninin faktörleri olan kadın ve erkek çalışanların araştırmaya konu edilen örgütsel adalet, örgütsel adalet boyutları, örgütsel özdeşleşme ve işten ayrınla niyeti algıları arasında anlamlı bir bir fark olup olmadığ 1 araştırılmıştır. Analiz sonucunda kadın ve erkek çalışanların dağıtım adaleti algıları arasında ve ile işten ayrılma niyetleri arasında anlamlı bir fark olduğu belirlenmiştir $(p<.05)$. Diğger araştırma değişkenlerinde ise kadın ve erkek çalışanların algıları arasında anlamlı bir fark olmadığı belirlenmiştir. Araştırma örnekleminin kamu ve özel olmak üzere iki sektörden belirlendiğinden yola çıkılarak kamu ve özel sektör çalışanlarının örgütsel adalet, örgütsel adalet boyutları, örgütsel özdeşleşme ve işten ayrınla niyeti algıları arasında anlamlı bir bir fark olup olmadığı araştırılmıştır. Analiz sonucunda çalışanların örgütsel adalet, örgütsel özdeşleşme ve işten ayrınla niyeti algılarının kamuda ve özel sektörde çalışmalarına göre farklılaştığ 1 tespit edilmiştir $(\mathrm{p}<.05)$.

Çalışanların işten ayrılma niyetine örgüt-

Tablo 1

Verilere ilişkin Ortalama, Standart Sapma ve Korelasyon Değerleri

\begin{tabular}{|l|c|c|c|c|c|c|c|}
\hline Değişkenler & Ort. & S.S. & $\mathbf{1}$ & $\mathbf{2}$ & $\mathbf{3}$ & $\mathbf{4}$ & 5 \\
\hline 1. Prosedür adaleti & 3.23 & .76 & $\mathbf{( . 7 6 )}$ & & & & \\
\hline 2. Etkileşim adaleti & 3.58 & .92 & $.688^{* *}$ & $\mathbf{( . 9 5 )}$ & & & \\
\hline 3. Dağıtım Adaleti & 3.22 & .85 & $.644^{* *}$ & $.564^{* *}$ & $\mathbf{( . 8 1 )}$ & & \\
\hline 4. Örgütsel Özdeşleşme & 3.88 & .69 & $.242^{* *}$ & $.134^{*}$ & $.265^{* *}$ & $\mathbf{( . 7 8 )}$ & \\
\hline 5. İşten Ayrılma Niyeti & 1,91 & .93 & $-.358^{* *}$ & $-.443^{* *}$ & $-.388^{* *}$ & $-.319^{* *}$ & $(.89)$ \\
\hline
\end{tabular}

$* \mathrm{p}<.05, * * \mathrm{p}<.01,($ ) Güvenilirlik 
sel adalet ve örgütsel özdeşleşme algılarının etkisini belirlemeye ilişkin kurulan yapısal eşitlik modelinin analiz sonuçları Şekil 2'de verilmektedir. Modelin uyum indeksleri incelendiğinde; GFI (Goodness of fit index) değerinin .87, AGFI (Adjusted goodness of fit index) değerinin .84, CFI (Comperative fit index-Karşılaştırmalı uyum indeksi) değerinin .93, TLI (Tucher- Lewis indeksi) değerinin .92, NFI ( Normlanmış uyum iyiliği indeksi .89, CMIN/DF değerinin 2,1, p değerinin .000 ve RMSEA (Root mean square error of approximation-Kök ortalama kare yaklaşım hatası) değerinin de 0.06 olduğu tespit edilmiştir. Bir modelin kabul edilmesi için RMSEA degerinin 0.08 altında olması gerekir (Şimsek, 2007). Elde edilen bu değerler kapsaminda verinin iyi uyum iyiliği değerleri ve standarda yakın değerler (>.90) verdiği için oluşturulan yapısal eşitlik modelinin kabul edilebilir olduğunu söylenebilir (Joreskog ve Sorbom, 1993; Kline, 1998)

Analiz sonuçları incelendiğinde prosedür adaletinin hem örgütsel özdeşleşmeyi hemde işten ayrılma niyetini anlamlı olarak etkilemediği belirlenmiştir. Etkileşim adaletlinin ise örgütsel özdeşleşmeyi anlamlı olarak etkilemediği ancak işten ayrılma ni- yeti üzerinde negatif ve anlamlı bir etkisinin olduğu tespit edilmiştir. Örgütsel adaletin üçüncü boyutu olan dağıtım adaletinin ise diğer boyutlardan farklı olarak hem örgütsel özdeşleşmeyi hemde işten ayrılma niyetini anlamlı olarak etkilediğ $i$ bulgusuna ulaşılmıştır. Bir diğer değişken olarak analize dahil edilen örgütsel özdeşleşme değişkeninin de beklendiği şekilde işten ayrılma niyeti üzerinde negatif ve anlamlı bir etkisinin olduğu tespit edilmiştir.

Analiz sonucunda değişkenler ayrı ayrı incelendiğinde özellikle dağıtım adaletinin işten ayrılma niyetine etkisinde çalışanların örgütsel özdeşleşme düzeyinin aracılık etkisinin olabileceğine ilişkin bulgulara rastlanılmış olması dikkat çekmektedir. Baron ve Kenny (1986, Aktaran Şimşek, 2007:25,31) tarafından önerilen ara değişken koşulları kapsaminda veriler analiz edilmiştir.

Bu kapsamda her üç değişken arasında anlamlı ilişki ve etkilerin bulunması aracılık ilişkisinin araştırılmasının gerekli kılmıştır. Yapılan yol analiz sonucunda dağıtım adaleti ile işten ayrılma niyeti arasındaki standardize edilmiş toplam, direkt ve endirekt etkiler belirlenmiştir. İki değişken arasında tespit edilen - .07 oranındaki endirekt etki

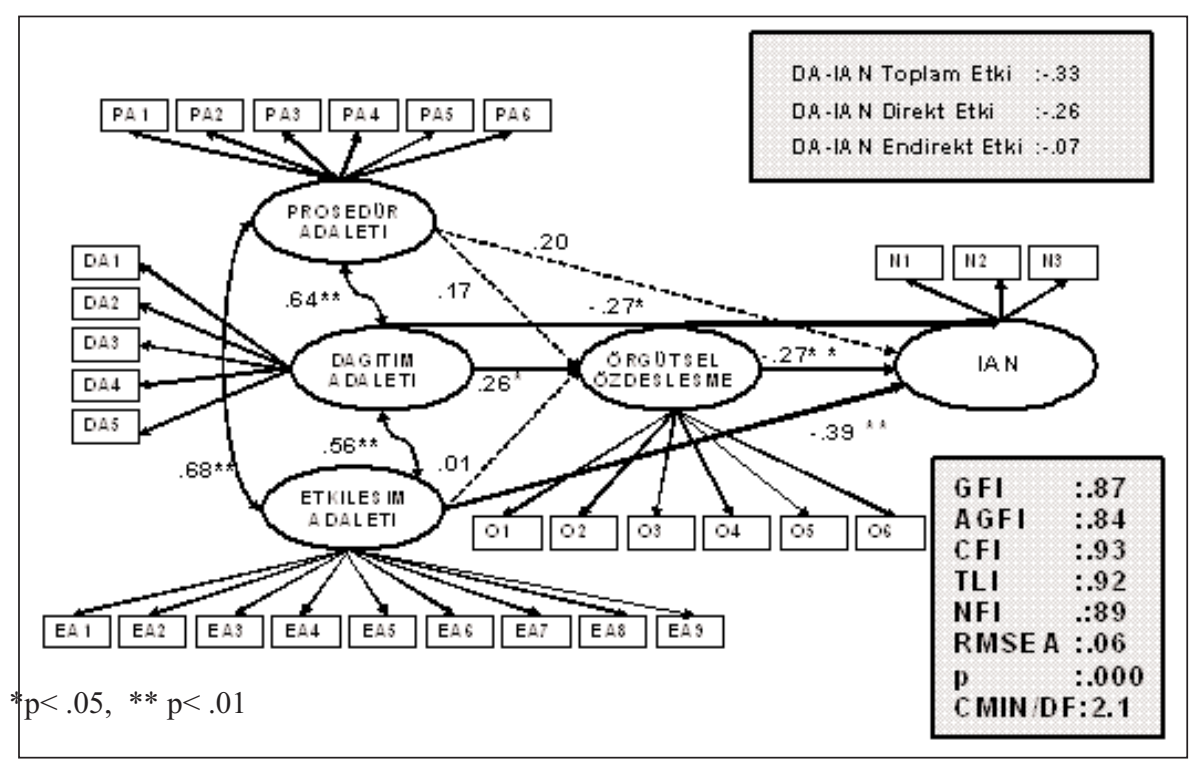

Şekil 2

Yapısal Model ve Analiz Sonuçları 
modelde yer alan örgütsel özdeşleşme değişkeninin dağıtım adaleti ile İşten ayrılma niyeti arasında aracılık etkisi olabileciği ortaya koymaktadır. Toplam, direkt ve endirekt etkilere ilişkin bilgiler Şekil 2'de toplu halde verilmektedir. Bu noktadan hareketle tahmin edilen aracılık etkisini belirlemek için farklı bir analiz yöntemi kullanılarak araştırmaya devam edilmiştir.

Çalışanların örgütsel özdeşleşme algisının prosedür adaleti, dağıtım adaleti, etkileşim adaleti ile IAN arasındaki aracılık etkisini rolünü açıklamak amacıyla, Baron ve Kenny (1986) tarafından önerilen üç aşamalı regresyon analizi yapilmıştır. Bu yönteme göre, aracılık etkisinden söz edilebilmesi için üç şartın var olması gerekmektedir:

(1) Bağımsız değişkenin aracı değişken üzerinde bir etkisi olmalidir.

(2) Bağımsız değişkin bağımlı değişken üzerinde etkili olmalıdır.

(3) Aracı değişken (örgütsel özdeşleşme) ikinci adımdaki regresyon analizine dâhil edildiğinde, bağımsız değişkenin bağımlı değişken üzerindeki regresyon katsayısı düşerken, aracı değişkenin (örgütsel özdeşleşme) de bağımlı değişken (İAN) üzerinde anlamlı bir etkisi olmalıdır.

$\mathrm{Bu}$ kapsamda çalışanların örgütsel özdeşleşme düzeyinin arac1lık rolünü belirlemek amacıyla, bu değişkenle prosedür adaleti, dağ1tım adaleti, etkileşim adaleti ve IAAN arasındaki ilişkiler hiyerarşik regresyon analizleri aracıllığ1 ile incelenmiştir. Aracılık testine ilişkin bulgular Tablo 2'de verilmektedir.

Aracilık testi kapsamında ilk aşamada cinsiyet ve sektör(kamuözel) kontrol değişkenleri ile birlikte bağımsız değişkelerin aracı değişken rolü araştırılan örgütsel özdeşleşme üzerindeki etkileri araştırılmıştır. Bu kapsamda yapılan hiyerarşik regresyon analizi sonucunda sektör $(=-.23$, $\mathrm{P}<.01)$, prosedür adaleti $(=.23, \mathrm{P}<.01)$ ve dağttım adaletinin( $=.21, \mathrm{P}<.01)$ örgütsel özdeşleşmeyi anlamlı olarak etkilediği tespit edilmiştirDiğer değișkenlerin örgütsel özdeşleşmeyi anlamlı olarak etkilemediği görülmüştür.

Tablo 2

Aracılık Testi Sonuçları

\begin{tabular}{|c|c|c|}
\hline & $\begin{array}{c}\text { Örgütsel } \\
\text { Özdeşlesşme }\end{array}$ & $\begin{array}{l}\text { İşten Ayrılma } \\
\text { Niyeti }\end{array}$ \\
\hline \multicolumn{3}{|l|}{ Test 1} \\
\hline Cinsiyet & .60 & \\
\hline Sektör & $-.23^{* *}$ & \\
\hline Prosedür Adaleti & $.23^{* *}$ & \\
\hline Dağıtım Adaleti & $.21^{* *}$ & \\
\hline Etkileşim Adaleti & -.75 & \\
\hline$R^{2}$ & 13 & \\
\hline \multirow[t]{2}{*}{ Uyarlanmış $R^{2}$} & .11 & \\
\hline & $\left(F=9.5^{* *}\right)$ & \\
\hline \multicolumn{3}{|l|}{ Test 2} \\
\hline Cinsiyet & & -0.06 \\
\hline Sektör & & .03 \\
\hline Prosedür Adaleti & & -.02 \\
\hline Dağıtım Adaleti & & $-.17^{* *}$ \\
\hline Etkileşim Adaleti & & $-.34^{* *}$ \\
\hline$R^{2}$ & & .23 \\
\hline \multirow[t]{2}{*}{ Uyarlanmış $R^{2}$} & & .22 \\
\hline & & $\left(F=18.65^{* *}\right)$ \\
\hline \multicolumn{3}{|l|}{ Test 3} \\
\hline Cinsiyet & & -.05 \\
\hline Sektör & & -.02 \\
\hline Prosedür Adaleti & & -.03 \\
\hline Dağıtım Adaleti & & -.13 \\
\hline Etkileşim Adaleti & & $-.35^{* *}$ \\
\hline Örg. Özdeşleşme & & $-.25^{* *}$ \\
\hline Cinsiyet & & -.05 \\
\hline$R^{2}$ & & .28 \\
\hline \multirow[t]{2}{*}{ Uyarlanmış $R^{2}$} & & .27 \\
\hline & & $\left(F=20.35^{* *}\right)$ \\
\hline
\end{tabular}

Tablodaki değerler standardize edilmiș Beta'dır. $* \mathrm{p}<.05, * * \mathrm{p}<.01$ 
İkinci aşamada ise bağımsız değişkenlerin bağımlı değișken olan İAN üzerindeki etkileri analiz edilmiştir. Analiz sonucunda dağıtım adaleti $(=-.17, \mathrm{P}<.01)$ ve etkileşim adaleti $(=-.34, \mathrm{P}<.01)$ değişkeninin İAN'ni negatif ve anlamlı olarak etkilediği belirlenmiştir. Diğer değişkenlerin İAN' ni anlamlı olarak etkilemediği görülmüştür. Analizin iki aşaması sonucunda örgütsel özdeşleşme ara değişkeninin sadece dağıtım adaleti ile IAN arasında aracılık rolü olabileceğine işaret eden ön şartların sağlandığı görülmüştür. $\mathrm{Bu}$ bulgu Amos analiz sonucunda elde edilen aracılık belirtisini doğrulamıştır.

Aracılık etkisi ön şartını sağlanmasının ardından üçüncü aşamada aracı değişkende dâhil edilerek analize devam edilmiştir. Analiz sonucunda örgütsel özdeşleşme değişkeninin de tüm bağımsız değişkenlerin bağımlı değişken üzerindeki etkilerinin araştırıldığı sürece dâhil edilmesiyle ilk iki aşamada ara ve bağımlı değişken üzerinde anlamlı etkisi dağıtım adaleti değişkeninin anlamlığını kaybetmesine rağmen örgütsel özdeşleşme değişkeninin pozitif ve anlamlı etkisi olduğu belirlenmiştir( $\beta=.23, \mathrm{P}<.01)$. $\mathrm{Bu}$ bulgular dağıtım adaleti algılarının İAN'nin azaltılmasında örgütsel özdeşleşmenin tam aracılık etkisi olduğunu istatistikî olarak doğrulamaktadır. Aracılık testi sonuçları

Analiz kapsaminda modelde çoklu doğrusal bağlantı sorunu olup olmadığını belirlemek maksadıyla doğrudaşlığa (collinearity) da bakılmıştır. Elde edilen tolerans ve VIF değerleri bağımsız değişkenler arası çoklu bağlantı olmadığını doğrulayan sonuçlar vermiştir (Tolerans $>$.6, VIF $<10$ )

Modele ilişkin hipotez testi sonuçları toplu halde tablo 2'de verilmektedir. Tabloda da görüldüğü gibi prosedür adaletinin örgütsel özdeşlemeye etkisini araştıran $\mathrm{H1a}$, etkileşim adaletinin örgütsel özdeşlemeye etkisini araştıran H1c ve prosedür adaletinin işten ayrılma niyetine etkisini araştıran $\mathrm{H} 2 \mathrm{a}$ hipotezleri desteklenmemiştir. Buna karşın dağıtım adaletinin örgütsel özdeşleşmeye etkisini araştıran H1b, Örgütsel özdeşleşmenin işten ayrılma niyetine etkisini araştıran $\mathrm{H} 3$, dağıtım daletinin işten ayrılma niyetine etkisini araştıran $\mathrm{H} 2 \mathrm{~b}$ ve etkileşim adaletinin işten ayrılma niyetine etkisini araştıran $\mathrm{H} 2 \mathrm{c}$ hipotezleri bulgularla desteklenmiș ve kabul edilmiștir. Sonuç olarak araştırılan yedi hipotezden dördü destek bulmuştur.

\section{Tartışma ve Sonuç}

$\mathrm{Bu}$ çalışma ile prosedür adaleti, dağıtım adaleti, etkileşim adaleti, örgütsel özdeşleşme ve işten ayrılma niyeti arasındaki ilişki ve etkiler incelenmiştir. Bu amaçla savunma ve bankacılık sektörü çalışanları (kamu ve özel) üzerinde bir araştırma yapılmış, örgütsel adaletin boyutları olan prosedür, dağıtım ve etkileşim adaletinin örgütsel özdeşleşme ve işten ayrılma niyeti üzerindeki etkileri

\section{Tablo 3}

Hipotez Sonuçları

\begin{tabular}{|l|l|c|c|}
\hline & \multicolumn{1}{|c|}{ Hipotez } & Yol Katsayısı & Sonuç \\
\hline H1a & Prosedür Adaleti $\rightarrow$ Örg. Özdeşleşme & .17 & Desteklenmedi \\
\hline H1b & Dağıtım adaleti $\rightarrow$ Örg. Özdeşleşme & $.26^{*}$ & KABUL \\
\hline H1c & Etkileşim Adaleti $\rightarrow$ Örg. Özdeşleşme & .01 & Desteklenmedi \\
\hline H3 & Örg. Özdeşleşme $\rightarrow$ İAN & $-.27^{* *}$ & KABUL \\
\hline H2a & Prosedür Adaleti $\rightarrow$ İAN & .20 & Desteklenmedi \\
\hline H2b & Dağıtım adaleti $\rightarrow$ İAN & $-.27^{*}$ & KABUL \\
\hline H2c & Etkileşim Adaleti $\rightarrow$ İAN & $-.39^{* *}$ & KABUL \\
\hline p $<.05 * * \mathrm{p}<.01$ & & \\
\end{tabular}


oluşturulan bir model yardımıyla açıklanmaya çalıșılmıştır. Yapılan araştırma ile özellikle günümüzde hizmet sektörünün öncü sektörlerinden birisi olan bankacılık sektörü ile nitelikli işgücünün yoğun istihdamının olduğu savunma sektöründe konu edilen değişkenlere ilişkin bulgular elde edilmiştir.

Analiz sonuçları incelendiğinde prosedür adaletinin örgütsel özdeşleşmeyi anlamlı olarak etkilemediği belirlenmiştir. Bu bulgu benzer çalışmalarla uyumlu değildir(Olkkonen ve Lipponen, 2006; Cheung ve Law, 2008) Prosedür adaletinin benzer şekilde işten ayrılma niyetini anlamlı olarak etkilemediği belirlenmiştir. Bu bulgu da benzer çalışmalarla uyumlu değildir(DeCorninck ve Stilwell, 2004; Byrne, 2005; Colquitt vd. 2001; Brashear vd., 2005). Prosedür adaletinin hem örgütsel özdeşleşme hemde işten ayrılma niyetini anlamlı olarak etkilememesinin iki sebebinin olabileceği değerlendirilmektedir. Bunlardan ilkinin uygulamanin yapıldığ1 sektörlerden kaynaklanan bir sonuç olduğu düşünülmektedir. Nitekim bankacılık sektöründe prosedüre ilişkin esnekliğin neredeyse sıfıra yakın dir. Ayrıca diğer sektör olan savunma sektöründe de kamu çalışanlarının çoğunlukta olması ve bürokratik süreçlerin katılımı zorlaştırması gibi etkenlerin varlığının bu sonuca ulaşılmasında önemli bir etken olduğu düşünülmektedir. İkinci nedenin de ekonomik kriz olabileceği düşünülmektedir. Nitekim içinde bulunduğumuz kriz döneminde çalışanların birincil önceliklikleri genellikle prosedürlerin belirlenmesine katılım değil işinde kalabilmektir.

Araştırma sonuçlarına göre çalışanların etkileşim adaleti algılarının örgütsel özdeşleşmeyi anlamlı olarak etkilemediği belirlenmiştir. Bu bulgu bazı çalışmalarla uyumlu (Olkkonen ve Lipponen, 2006) Cheung ve Law (2008) tarafından yapılan çalışma ile uyumlu değildir. Bunun yanında etkileşim adaletlinin işten ayrılma niyeti üzerinde negatif ve anlamlı bir etkisinin olduğu tespit edilmiştir. Bu bulgu Nadiri ve Tanova (2009) 'un çalışmasıyla uyumludur. Etkileşim adaleti ile ilgili olarak elde edilen bu bulgunun seçilen örneklem ile uyumlu olduğu düşünülmektedir. Prosedür adaletinde olduğu gibi; araştırma yapılan her iki sektörde de çoğunlukla çalışanlar ve yönetim arasındaki etkileşimin adilliğini konu edinen etkileşim adaletinin içinde bulunduğumuz kriz döneminde örgütsel özdeşleşmeyi normal şartlardaki kadar etkilemeyeceği düşünülmektedir. Farklı şekilde, kültürümüzde işyeri ilişkilerinin pek çok şeyden önemli olduğundan hareketle yöentimle iyi etkileşimin işten ayrılma niyetini negatif yönde etkileyebileceği düşünülmektedir.

Örgütsel adaletin üçüncü boyutu olan dağtım adaletinin örgütsel özdeşleşmeyi anlamlı olarak etkilediği bulgusuna ulaşılmıştır. Bu bulgu benzer çalışmalarla uyumludur(Olkkonen ve Lipponen, 2006; Cheung ve Law, 2008). Benzer şekilde dağ1tım adaletinin işten ayrılma niyetini negatif anlamlı olarak etkilediği tespit edilmiştir. Bu bulgu bazı çalışmalarla uyumludur(Colquitt vd. 2001; Brashear, 2005; McFarlin ve Sweeney, 1992). Bu bulgunun beklenildiği şekilde tespit edilmesinin dağıtım adaletinin içinde bulunduğumuz dönemle önemli derecede ilişkili olmasından kaynaklandığı düşünülmektedir. Organizasyonda eide edilen çıktıların adil bir şekilde paylaşılması ya da dağıtılması ile açıklanabilen dağıtım adaletinin ekonomik kriz ve işsizlik döneminde çoğu sektörde çalışanları etkileyen başlıca etkenlerden biri olarak düşünüldügüünde örgütsel özdeşleşme ve işten ayrılma niyeti üzerinde anlamlı ve beklenen etkilerinin tespit edilmesinin çok olağan olduğu sanılmaktadir.

Bir diğer değişken olarak analize dâhil edilen örgütsel özdeşleşme değişkeninin de beklendiği şekilde işten ayrılma niyeti üzerinde negatif ve anlamlı bir etkisinin olduğu tespit edilmiştir. Bu bulgu Dick ve arkadaşlarının (2004) araştırmalarıyla uyumlu, bazı çalışmalarla uyumlu değildir (Mignonac vd, 2006, Van Kinippenberg ve Van Schie). Elde edilen bulgunun beklenen şekilde olmasının örgütsel özdeşleşmenin kültürümüzdeki öneminden kaynaklandığı düşünülmektedir. 
Nitekim ele alınan örneklemin dahil olduğu iş kültüründe çalışanlar çoğunlukla çalıştıkları iş ile özel bir bağ kurarlar. Bu bağın olumlu olması genellikle -pek çok neden olsa bile- işte kalma niyetlerininde önemli bir neden teşkil eder. Bu nedenle elde edilen bulgunun uyumlu olduğu düşünülmektedir.

Çalışmada örgütsel özdeşleşme değişkenin bağımsız değişkenler ile bağımlı değişken İAN aeasinda aracilık rolü olup olmadığı da incelenmiştir. Bu kapsamda yapılan analizler sonucunda çalışanların örgütsel özdeşleşmesinin dağıtım adaleti alg1ları ile İAN 'leri arasında tam aracılık rolü üstlendiği tespit edilmiştir.

Araştırma kapsaminda cinsiyet (kadın/erkek) ve sektör (kamu/özel) değişkenleri ile $\mathrm{t}$ testi yapılmıştır. Analiz sonucunda kadın ve erkek çalışanların dağıtım adaleti algıları arasında ve ile işten ayrılma niyetleri arasında anlamlı bir fark olduğu belirlenmiştir $(p<.05)$. Örgütsel çıtılırın dağitılmasında ve işten ayrılma niyetinde cinsiyetin etkilerinin olabileceği zaten öngörülmüş bir durum olmasına rağmen diğer değişkenlerde anlamlı fark bulunamaması araştırma açısından beklenilmeyen bir sonuç olmuştur. Kadın ve erkeklerin prosedür adaleti, etkileşim adaleti algıları ile örgütsel özdeşleşme düzeyleri arasında anlamlı bir fark olmadığ 1 belirlenmiştir. Ayrıca araştırma örnekleminin kamu ve özel olmak üzere iki sektörden belirlendiğinden yola çıkılarak kamu ve özel sektör çalışanlarının örgütsel adalet, örgütsel adalet boyutları, örgütsel özdeşleşme ve işten ayrılma niyeti algıları arasında anlamlı bir bir fark olup olmadığ araştırılmıştır. Analiz sonucunda çalışanların tüm değişken algılarının kamuda ve özel sektörde çalışanlara göre anlamlı olarak farklılaştı̆̆ 1 tespit edilmiştir $(\mathrm{p}<$.05). Bunun nedeninin ise kamu çalışanlarının düşük gelir düzeyi ve motivasyon eksikliğinden kaynaklandığı düşünülmektedir. Nitekim yoğun iş yüküne rağmen düşük ücret, kariyer fırsatlarının olmayışı gibi motivasyon eksikliklerinin çalışanların adalet, özdeşleşme ve İAN'ni farklılaştırabildiği düşünülmektedir.
Sonuç olarak, çalışanların örgütsel adalet algılarının örgütsel özdeşleşme ve işten ayrilma niyeti üzerinde etkisinin olduğu belirlenmiştir. Bu etkiler örgütsel adaletin boyutları ile diğer bağımlı değişkenler arasinda farklılıklar göstersede oluşturulan yapisal eşitlik modeline göre elde edilen bulgulan data ile uyumludur. Bu kapsamda ele alınan örneklem üzerinde adalet, özdeşleşme ve işten ayrılma niyeti değişkenlerinin aralarında oluşturulan modelin uyumlu olduğu tespit edilmiştir. Araştırma kapsaminda örgütsel adalet boyutlarından olan dağıtım adaletinin işten ayrılma niyetini negatif ve anlamlı olarak etkilediği bulgusunun yanında bu etkide örgütsel özdeşleşmenin aracılık rolü olduğuna ilişkin bulgular elde edilmiş olması çalışmanın önemli bir sonucudur. Böyle bir bulgunun yerli literatürde yeni ve ilk olmasının araştırmacılar için önemli bir kaynak olacağı düşünülmektedir.

Kamu çalışanları ile özel sektör çalışanlarının adalet, özdeşleşme ve işten ayrılma niyeti algıları aranında anlamlı bir fark bulunması kamu yöneticilerinin nitelikli çalışanların işte kalmalarına yönelik tedbirler alması gereğine dikkat çekmektedir. Özellikle dağıtım adaleti gibi çalışanların kazanımlarıyla alakalı dengenin sağlanmasının bu bağlamda bir çözüm önerisi olabileceği düşünülmektedir. Nitekim nitelikli işgücüne ödene ücretler kamu ve özel sektörde önemli farkl1lıklar göstermektedir. Bu çerçevede kamu sektöründe nitelikli işgücünün işten ayrılma niyetinin azaltılması bağlamında araştırma modelinde ortaya konulan değişken etkilerinin dikkate alınarak tedbirler alınmasının önemli olduğu düşünülmektedir.

Bütün bunların yanı sıra araştırmanın bazı sınırlılıkları bulunmaktadır. Araştırmanın yapıldığ 1 sektörler, yapı itibariyle diğer sektörlerden farklilık göstermektedir. Yoğun çalışma ve stresli iş ortamı, rekabet, sürekli ve hızla değişen çevre şartları, kadın çalışan sayısının fazlalılığı bu farklılıklardan bazılarıdır. Bu nedenle farklı sektörlerde yapılacak araştırmalardan farklı sonuçlar elde edilebilir. Bunun yanı sıra araştırmada kullanılan 
veriler bankanın ve savunma sektörünün belli bir coğrafi bölgesindeki çalışanlarından elde edilmiştir. Farklı coğrafi bölgelerdeki çalışanlardan elde edilecek verilerle daha açıklayıcı sonuçlara ulaşılması mümkün olabilir.

$\mathrm{Bu}$ araştırmanın örgütsel adalet- örgütsel özdeşleşme- işten ayrılma niyeti ilişkisini belirlemeye yönelik bir çalışma olması ve araştırma metodolojisi açısından diğer çalışmalardan kısmen farklı olduğu düşünülmektedir. Araştırmanın yapısal eşitlik modeli ile modelin veriye uyumluluğunu belirlemeye yönelik bir çalışma olması ve adalet-özdeşleşme- işten ayrılma niyeti değişkenleri ile örgütsel özdeşleşmenin arac1lık rolünü ele alması açısından bundan sonraki çalışmalar için faydalı olabileceği düşünülmektedir. Ayrıca bu araştırmada da kullanılan gizli değişkenlerle yol analizi, farklı modellerin ve farklı değişkenlerin aynı anda test edilmesine imkân tanıyan bir yöntemdir. Böylece birbirini etkileyen değişkenlerin bir bütün olarak ve aynı anda değerlendirilmesi mümkün olabilmektedir. Özellikle örgütsel davranış gibi insan faktörünün son derece önemli olduğu bir alanda, karmaşık faktörler ve değişkenler arasındaki ilişkilerin oluşturulacak modellerle test edilmesi, yönetim ve insan kaynakları yönetimi açısından daha tatmin edici sonuçlar verebilir. Bu nedenle, gelecekte yönetim ve organizasyon alanında yapılacak çalıșmalarda bu yöntemin kullanılmasının daha çok desteklenmesi gerektiği düşünülmektedir.

\section{Kaynakça}

Adams, J.S. (1963) "Toward an Understanding of Inequity" Journal of Abnormal and Social Psychology, ss. 422-436.

Adams, J.S. (1965) "Inequity in Social Exchange", içinde Berkowitz, L (Ed.), Advances in Experimental Social Psychology, Academic Press, New York London, Vol.2, ss.267-299.

Alexander, S. ve Ruderman, M. (1987) “The Role of Procedural and Distributive Justice in Organizational Behavior, .Social Justice Research, 1: 177-98.

Alexander, S., Sinclair, R.R. ve Tetrick, L.E. (1995) "The Role of Organizational Justice in Defining and Maintaining the Employment Relationship" içinde Tetrick, L.E. and Barling, J. (Ed.) Changing Employment Relations: Behavioral and Social Perspectives. Washington, Dc: American Psychological Association.

Ang, S., Dyne, L. V. ve Begley T. M., (2003) "The Employment Relationships of Foreign Workers versus Local Employees: a Field Study of Organizational Justice, Job Satisfaction, Performance and OCB", Journal of Organizational Behavior, 24, ss.561-583.

Ashforth, B. E. ve Mael F. (1989) "Social Identity Theory and the Organizations", Academy of Management Review, 14, 20-39.

Barclay, L. J., Skarlicki, D. P., ve Pugh, S. D. (2005) "Exploring the Role of Emotions in Injustice Perceptions and Retaliation", Journal of Applied Psychology, 90, ss.629-643.

Baron, R. M., ve Kenny, D. A. (1986). “The Moderator Mediator Variable Distinction in Social Psychological Research: Conceptual, Strategic, and Statistical Considerations", Journal of Personality and Social Psychology, 51, ss.1173-1182.

Beugre, C.D. (1998) Managing Faimess in Organization,. Westport, CT: Quorum Books. 
Bhattacharya, R., (1998) "A Formal Model of Trsut Based on Outcomes", Academy of Management Review, 23:3.

Brashear, B. ve Zinta, S. (2005), "Fairness Reduces the Negative Effects of Organizational Politics on Turnover Intentions, Citizenship Behavior and Job Performance", Journal of Business and Psychology, Vol. 20, No. 2.

Brett, J. M. ve Goldberg, S. B. (1983) "Mediator-Advisors: A New Third-Party Role" Bazerman, M. ve Lewicki, R. (Ed.), Research on Negotiations in Organizations, Greenwich, Ct: Ja1 Pres, ss.81-90.

Byrne Z. S. (2005) "Fairness Reduces the Negative Effects of Organizational Politics on Turnover Intentions, Citizenship Behavior and Job Performance, Journal of Business and Psychology, Vol. 20, No. 2.

Chang E., (2002) “Distributive Justice and Organizational Commitment Revisited: Moderation by Layoff in the Case of Korean Employees", Human Resource Management, Summer, Vol. 41, No. 2.

Chebat, J., ve Slusarczyk, W. (2005) "How Emotions Mediate the Effects of Perceived Injustice on Loyalty in Service Recover Situations: An Empirical Study", Journal of Business Research, 58, ss.664673.

Cheney, G. (1983) "On the Various and Changing Meaning of Organizational Membership: a Field Study of Organizational Identification", Communication Monographs, 50.

Colquitt, J. a., Conlon, D. E., Wesson, M. J., Porter, C. O. L. H., ve Ng, K. Y. (2001). "Justice At the Millennium: a MetaAnalytic Review of 25 Years of Organizational Justice Research, Journal of Applied Psychology, 86, 425-445.

Cropanzano, R., Folger, R., (1991) "Procedural Justice and Worker Motivation" içinde Steers, R.M., Porter, L.W. (Eds.), Motivation and Work Behavior. Mcgraw-Hill, New York.
Cropanzano, R. S, Randall, M. (1993) “Justice in the Workplace: a Historical Review" içinde Cropanzano, R. (Ed.), Justice in the Workplace: Approaching Fairness in Human Resource Management Erlbaum, Hillsdale, NJ, ss. 3-20.

Cropanzano, R.S. ve Kackmar, K.M. (1995) Organizational Politics, Justice and Support: Managing the Social Climate of the Workplace, Westport, Ct: Quorum Books.

Cropanzano, R.S. ve Randall, M.L. (1993) "Injustice and Work Behaviour: a Historical Review" içinde Cropanzano, R.S. (Ed.) Justice in the Workplace: Approaching Faimess in Human Resource Management. Hillsdale, Nj: Lawrence Erlbaum, ss. 3-20.

Deconinck, J. B., Stilwell, C. D. (2004) "Incorporating Organizational Justice, Role States, Pay Satisfaction and Supervisor Satisfaction in a Model of Turnover Intentions", Journal of Business Research, 57 , ss. 225- 231.

Deconninck, J., (2005) “An Analysis of Turnover Amaong Retail Buyers", içinde Bachmann, D. (Ed.) Journal of Business Research, Vol.58, ss. 874- 882.

Decremer, D., (2006) "When Authorities Influence Followers" Affect: the Interactive Effect of Procedural Justice and Transformational Leadership", European Journal of Work and Organizational Psychology, 15, , ss.322-351.

Dreher, G. F. (1982). "The Role of Performance in the Turnover Process, the Academy of Management Journal, 25,1: 137-174.

Dutton, J. Dukerich, J.ve Harquail, C.V. (1994) "Organizational Images and Membership Commitment", Administrative Science Quarterly,34. 
Fields, D., Pang, M., Chiu, C., (2000) "A Comparative Field Study of the Effects of Distributive and Procedural Justice in Hong Kong." Journal of Organizational Behaviour, 21 (5), ss.547-562.

Folger, R, Konovsky, M. A. (1989), “Effects of Procedural and Distributive Justice on Reactions To Pay Raise Decisions", Academic Management Journal, 32(1), ss.115- 30 .

Folger, R. (1989) "Significance Tests and the Duplicity of Binary Decisions", Psychological Bulletin, 106, ss.155-160.

Folger, R. ve Cropanzano, R.S., (1998), Organizational Justice and Human Resource Management, Thousand Oaks, CA: Sage,

Fryxell, G.E. ve Gordon, M.E. (1989) "Workplace Justice and Job Satisfaction As Predictors with Unions and Management", Academy of Management Joumal, 32, ss.851-66.

Gordon, M.E. ve Fryxell, G.E. (1993) “The Role of Interpersonal Justice in Organizational Grievance Systems" içinde Cropanzano, R. (Ed.) Justice in Tiie Workplace: Approaching Fairness in Human Resources Management. Hillsdale, Nj: Lawrence Eribaum, ss. 231-55.

Greenberg, J. (1987) “A Taxonomy of Organizational Justice Theories", Academy of Management Review, 12, ss. 9-22.

Greenberg, J. (1988) “Cultivating an Image of Faimess: Looking Fair on the Job", Journal of Applied Psychology. 73, ss.60613.

Greenberg, J. (1990) “Looking Fair Us Being Fair: Managing Impressions of Organizational Justice" ,(Ed.) Staw, B.M., Cummings, L.L., Research in Organizational Behavior, Jai Press, Greenwich, Ct, Vol. 12, ss.111-57.
Greenberg, J. (1993) "Justice and Organizational Citizenship: A Commentary on the State of Science", Empioyee Responsibility and Rights Joumal. 6, ss.249-56.

Greenberg, J. (1996) The Quest For Justice: Es.Says and Experiments, Thousand Oaks, Ca: Sage.

Greenberg, J. (1996), The Quest For Justice: Essays and Experiments. Thousand Oaks, Ca: Sage.

Griffeth, R.W. Hom, P.W. ve Gaertner, (2000). a Meta-Analysis of Antecedents and Correlates of Employee Turnover: Update, Moderator Tests, and Research Implications For the Next Millennium, Journal of Management, Vol.3, ss.463488.

Hartley, J. (1995) "Challenge and Change in Employment Relations: Issues For Psychology, Trade Unions and Managers" içinde Tetrick, L.E. ve Barling, J. (Ed.) Changing Empioyment Relations: Behavioural and Social Perspectives. Washington, DC: American Psychological Association.

Jackofsky, E. F. (1984) "Turnover and Job Performance: an Integrated Process Model", The Academy of Management, Vol.9, ss. 74-83.

Joreskog, K. G. ve Sorbom, D.(1993) Lisrel 8: Structural Equation Modeling with the SIMPLIS Command Language. Chicago, IL: Scientific International Software.

Karaeminoğulları, A. (2006), Öğretim Elemanlarının Örgütsel Adalet Algıları İle Sergiledikleri Üretkenliğe Aykırı Davranışlar Arasındaki İlişki ve Bir Araştırma, Yayımlanmamış Yüksek Lisans Tezi, İstanbul.

Kline, R. B., (1998) Principles and Practice of Structural Equation Modeling. New York: the Guilford Press. 
Kreiner, G. E. ve Ashforth, B. E. (2004) “Evidence Toward an Expanded Model of Organizational Identification". Journal of Organizational Behavior, 25.

Küçükusta, D. (2007), Konaklama İşletmelerinde İş-Yaşam Dengesinin Çalışma Yaşamı Kalitesi Üzerindeki Etkisi, Yayımlanmamış Doktora Tezi, İzmir.

Leventhal, G. S. (1980) “What Should Be Done with Equity Theory? New Approaches to the Study of Fairness in Social Relationships" içinde Gergen, K. Greenberg, M., ve Willis, R. (Ed.), Social Exchange: Advances in Theory and Research ,New York: Plenum Pres, ss. 27-55

Lind, E.A. ve Tyler, T.R.(1988) The Social Psychoiogy of Procedural Justice, New York and London: Plenum Pres.

Lind, E.A. (1995) "Justice and Authority in Organizations" içinde Cropanzano, R. ve Kacmar, K.M. (Ed.) Organizational Politics, Justice and Support. Westport, Ct: Quorum Books, ss. 83-96.

Lindquist, T. M. (1995), "Fairness As an Antecedent To Participative Budgeting: Examining the Effects of Distributive Justice, Procedural Justice and Referent Cognitions on Satisfaction and Performance", Journal of Management Accounting Research, Volume Seven, Fall.

Mael ,F. ve Tetrick, L.E. (1992) “Identifying Organizational Identification", Educational and Psychological Measurement, $52,813-824$.

Mael, F. ve Ashforth, B. (1992) "Alumni and Their Alma Mater: a Partial Test of the Reformulated Model of Organizational Identification", Journal of Organizational Behavior, Vol 13.

Mcfarlin, D., ve Sweeney, P. (1992). Distributive and Procedural Justice As Predictors of Satisfaction with Personal and Organizational Outcomes. Academy of Management Journal, 35, 626-637.
Mcfarlin, D.B. ve Sweeney, P.D. (1992) “Distributive and Procedural Justice As Predictors of Satisfaction with Personal and Organizational Outcomes" , Academy of Management Journal, 353, ss. 626637.

Mİao, C. F.ve Evans, K. R. (2007) "The Impact of Salesperson Motivation on Role Perceptions and Job Performance-a Cognitive and Affective Perspective", Journal of Personal Selling ve Sales Management, Vol. XXVII, No., ss. 89-101.

Mignonac, K. ve Herrbach, O., Guerrero, S. "The interactive Evects of Perceived External Prestige and Need For Organizational İdentification on Turnover Intentions", Journal of Organizational ,27, ss. 571-584.

Millissa F. Y. Cheung ve Monica C. C. (2008) "Law, Relationships of Organizational Justice and Organizational Identification: the Mediating Effects of Perceived Organizational Support in Hong Kong", Asia Pacific Business Review, Vol. 14, No. 2, ss.213-231.

Moore, B. (1978) Injustice: The Social Bases of Obedience and Revolt. Whaite Plains, N.Y:M.E. Sharpe.

Moorman, R.H. (1991). "Relationship Between Organizational Justice and Organizational Citizenship Behaviors: Do Fairness Perceptions Influence Employee Citizenship?, Journal of Applied Psychology, 76, s.6.

Mowday, R.T. (1987) Equity Theory Predictions of Behavior in Organizations, içinde Steers M.R. Porter, L.W. (Ed), Motivation and Work Behavior (4. Ed), Mcgraw-Hill, New York, 89-110.

Nadiri, H.ve Tanova, C., (2009) "An investigation of the Role of Justice in Turnover intentions, Job Satisfaction, and Organizational Citizenship Behavior in Hospitality Industry", International Journal of Hospitality Management. 
Niehoff, R.T., Moorman, R.H, (1993). Justice As a Mediator of the Relationship Betweenmethods of Monitoring and Organizational Citizenship Behavior, Academy of Management Journal, 36.

Nurse L. (2005) "Performance Appraisal, Employee Development and Organizational Justice: Exploring the Linkages", Int. J. of Human Resource Management, 16:7, ss. 1176-1194.

Okun, A. M. (1975) Equality and Efficiency: the Big Traide off, The Brookings Institution, Washington DC.

Olkkonen M.E. ve Lipponen, J. (2006) “Relationships Between Organizational Justice, İdentiwcation withorganization and Work Unit, and Group-Related Outcomes", Organizational Behavior and Human Decision Processes 100, ss.202-215.

Özdevecioğlu, M. (2003) “Algılanan Örgütsel Adaletin Bireyler Arası Saldırgan Davranışlar Üzerindeki Etkilerinin Belirlenmesine Yönelik Bir Araştırma", Erciyes Üniversitesi İktisadi ve İdari Bilimler Fakültesi Dergisi, Say1: 21: 77-96.

Porter, L., Steers, R., Mowday, R. ve Boulian, P. (1973), "Organizational Commitment, Job Satisfaction, and Turnover Among Psychiatric Technicians", Journal of Applied Psychology, Vol.59, No 5, ss.603-609.

Pratt, M.G. (1998) "To Be Or Not To Be": Centarl Question in Organizational Identification" Identity" içinde Whetten D.A ve Godfrey P.C.(Ed) Organizations: Building Theory Through Conversation, Thousand Oaks, CA: Sage Publications.

Rusbelt, F., Rogers, M. (1998) "Impact of Exchange Variables on Exit, Voice, Loyalty and Neglect: an Integrative Model of Responses to Decline Job Satisfaction", Academy of Management Journal, Vol.31 No:2, ss.599-627.
Scott, S.G. ve Lane, V.R. (2000) "A Stakeholder Approach To Organizational Identity", Academy of Management Review, $25: 1$.

Sekaran, U. (1992) Research Methods For Business, Canada: John Wiley ve Sons, Inc.

Shaw, J.D., Delery, J.E., Jenkins, G.D., Gupta, N., (1998) "An Organization-Level Analysis of Voluntary and Involuntary Turnover. Academy of management Review , 41 (5), 511-525.

Sheppard, B.H., Lewicki, R.J. ve Minton, J.W. (1992) Organizational Justice: the Search For Faimess in the Workplace New York: Lexington Books.

Smitdhs, a. Pryun, a. ve Van Riel, C.B.M. (2001), "The Impact of Employee Communication and Perceived External Prestige on Organizational Identification", Academy of Management Journal, 44:5.

Steensma, H. ve Vİsser, E. (2007), "Procedural Justice and Supervisors" Personal Power Bases: Effects on Employees" Perceptions of Performance Appraisal Sessions", Commitment, and Motivation," J. Collective Negotiations, Vol. 312 , ss. 101-118.

Sweeney, P. D. ve Mcfarlin, D. B. (1997) "Process and Outcome: Gender Differences in the Assessment of Justice", Journal of Organizational Behavior 18 (1): 83-98.

Şimşek, Ö. F. (2007) Yapısal Eşitlik Modellemesine Giriş: Temel İlkeler ve Lisrel Uygulamaları, Ekinoks, Ankara.

Tang, T. L., Sarsfield B. ve Linda J. (1996) Distributive and Procedural Justice As Related to Satisfaction and Commitment, Advanced Management Journal, C. 61, s.3. 
Taylor, M.S., Tracy, K.B., Renard, M.K., Harrison, J.K. ve Carroll, S.J. (1995) “Due Process in Performance Appraisal: a Quasi-Experiment in Procedural Justice", Administrative Science Quarterly, 40, ss.495-523.

Thibaut, J. ve Walker, L. (1978) A Theory of Procedure, California Law Review, 66, ss.541-566.

Thibaut, J., ve Walker, L. (1975) Procedural Justice: a Psychological Analysis. Hillsdale, $\mathrm{Nj}$ : Erlbaum.

Tompkins, P.K. ve Cheney, G. (1985) “Communication and Unobtrusive Control in Contemporary Organizations", R.D. Mcphee ve P.K. Tompkins (Der). Organzaitional Communication: Traditional Themes and New Directions, Beverly Hills, CA:Sage.

Tornblom, K.Y., (1990) "The Social Psychology of Distributive Justice" içinde Scherer K.(Ed), the Nature and Administration of Justice:Interdiciplinary Approaches.Cambridge, England:Cambridge University Pres

Tüzün, İ. K. (2006), Örgütsel Güven, Örgütsel Kimlik ve Örgütsel Özdeşleşme İlişkisi; Uygulamalı Bir Çalışma, Yayımlanmamış Doktora Tezi, Gazi Üniversitesi, Ankara,

Van Dick, R., Christw, O., Stellmacherw, J., Wagnerw, U., Ahlswedew, O., Grubbaw, C., Hauptmeierw, M., Hfeldw H., C. Moltzenw, K., ve Tissington, P. A. (2004) "Should I Stay Or Should I Go? Explaining Turnover Intentions with Organizational Identification and Job Satisfaction", British Journal of Management, Vol. 15, ss.351-360.

Van Knippenberg, D. ve Sleebos, E. (2006) "Organizational Identification versus Organizational Commitment: Self-Definition, Social Exchange, and Job Attitudes", Journal of Organizational Behavior, 27, ss. 571-584.
Van Knippenberg, D. ve Van Schie E.C.M. (2000) "Foci Correlates of Organizational Identification", Journal of Occupational and Organizational Psychology, 73, 137-147.

Wayne S.J., Shore L. M. ve Linden R. C. (1997) "Perceived Organizational Support and Leader Member Exchange: A Social Exchange Perspective", Academy of Management Journal, Vol. 40.

Williams, S. (1999) "The Effect of Distributive and Prosedural Fustice on Performance", the Journal of Psychology, 1332 , ss.183-193.

Wood, R.C., (1997) “Personnel Management, Labour Turnover and the Role of Trade Unions" içinde Wood, R.C. (Ed.), Working in Hotels and Catering. International Thompson Business Press, Oxford.

Zapata-Phelan, C. P., Colquitt, J. A , Scott, B. A. ve Livingston, B., (2009) "Procedural Justice, Interactional Justice and Task Performance: the Mediating Role of Intrinsic Motivation", Organizational Behavior and Human Decision Processes, 108, ss.93-105. 
